\title{
Meningkatkan Semangat Belajar di Rumah dengan Teknik Mind Mapping pada Siswa Kelas 1 SD di Dusun Rokoro Desa Taro'an, Kecamatan Tlanakan, Kabupaten Pamekasan
}

\author{
${ }^{1}$ Indah Kuratul Aini, ${ }^{2}$ Ali Nurhadi \\ Institut Agama Islam Negeri Madura, Jl. Raya Panglegur Km. 4 Pamekasan 69371 \\ ${ }^{1}$ indahkuratulaini31@gmail.com, ${ }^{2}$ nurhadibk@gmail.com
}

\begin{abstract}
The Covid-19 pandemic has shifted teaching and learning activities from school to home. Students are given homework as a way of learning at home. However, this only burdens students and parents. We need a way to increase students' enthusiasm for learning. Therefore, the purpose of this study is to increase enthusiasm of student in learning at home with mind mapping techniques. It also aims to overcome their boredom in doing assignments that are piled up due to Covid-19 besides not understanding the subject matter. The research method used is action research, because this study applies an action learning at home using mind-mapping techniques. The results showed that learning by using mind mapping technique is able to improve the spirit of student learning because basically, they like learning with media images. Therefore, learning to use mind mapping is highly recommended for use because it can increase the enthusiasm for learning.
\end{abstract}

Keywords: Covid-19; Study at Home; Mind Mapping

\begin{abstract}
Abstrak
Pada masa pandemi Covid-19, kegiatan belajar mengajar dialihkan dari sekolah menjadi belajar di rumah. Siswa diberikan tugas rumah sebagai cara belajar di rumah. Namun, hal itu justru membebani siswa dan orang tua sehingga diperlukan cara untuk meningkatkan semangat belajar para siswa. Maka dari itu, tujuan penelitian ini adalah untuk meningkatkan semangat belajar siswa di rumah dengan teknik mind mapping dan untuk mengatasi kejenuhan siswa dalam mengerjakan tugas yang menumpuk akibat Covid-19 sementara mereka tidak memahami materi pelajaran dengan baik. Adapun metode penelitian yang digunakan adalah penelitian tindakan, karena penelitian ini menerapkan suatu tindakan belajar di rumah menggunakan teknik mind mapping. Hasil penelitian menunjukkan bahwa belajar dengan menggunakan teknik mind mapping mampu meningkatkan semangat belajar siswa karena pada dasarnya, siswa menyukai belajar dengan media gambar. Oleh sebab itu, belajar menggunakan mind mapping sangat diajurkan untuk digunakan karena mampu meningkatkan semangat belajar.
\end{abstract}

Kata Kunci: Covid-19; Belajar di Rumah; Mind Mapping

\section{Pendahuluan}

Belajar merupakan suatu kegiatan yang dilakukan guna memperoleh pengetahuan. Kegiatannya dapat dilakukan secara formal di sekolah 
maupun non formal di luar sekolah, seperti di rumah. Kegiatan belajar umumnya dilaksanakan siswa di sekolah dan dilanjutkan di rumah guna mengulang mata pelajaran yang dipelajari di sekolah. Belajar merupakan suatu aktivitas yang wajib dilakukan bagi siswa untuk memperoleh ilmu. Menurut Gagne, belajar diartikan sebagai suatu proses untuk mendapatkan pengetahuan, keterampilan, kebiasaan dan tingkah laku. Selanjutnya, ia lebih menekankan bahwa belajar merupakan suatu usaha untuk memperoleh pengetahuan atau keahlian melalui instruksi (Susanto, 2013: 1). Dari sini dapat disimpulkan bahwa belajar merupakan suatu kegiatan yang dilakukan untuk memperoleh pengetahuan dan keahlian melalui instruksi guru.

Terkait dengan itu, dibutuhkan motivasi belajar dalam meningkatkan semangat siswa untuk belajar. Menurut Khodijah, motivasi belajar merupakan kondisi psikologis yang mendorong seseorang untuk belajar (Fauziah, Rosnaningsih, \& Azhar, 2017: 50). Dorongan untuk belajar dapat memberikan rasa semangat untuk menekuni materi pelajaran. Selain itu, kegiatan belajar harus dilaksanakan di segala kondisi apapun, sebab ia merupakan sesuatu yang wajib dilakukan setiap warga negara karena merupakan salah satu tujuan bangsa, yakni mencerdaskan kehidupan bangsa sebagaimana terdapat dalam pembukaan UUD'45 alinea ke-4. Berdasarkan itu, pemerintah selalu mewajibkan siswa untuk belajar dalam kondisi apapun, seperti halnya saat ini di masa pandemi Covid-19 di mana kegiatan belajar di sekolah mulai pertengahan Maret 2020 mulai ditangguhkan dan dipindah ke rumah. Pemerintah mengeluarkan surat edaran untuk belajar di rumah dengan tujuan untuk menekan penyebaran virus Corona.

Belajar di rumah merupakan kegiatan non-formal sebab siswa tetap belajar tanpa harus bertatap muka dengan seorang guru. Karena itu, diperlukan media yang bisa mengantarkan siswa memahami materi pelajaran sesuai dengan jadwal pelajaran dan target pembelajaran. Untuk itu, pemerintah juga menginstruksikan agar belajar di rumah dilakukan menggunakan media virtual, meski program ini tidak sepenuhnya berjalan dengan efektif. Hal itu terbukti pada daerah pelosok yang tidak menerapkan belajar di rumah menggunakan media virtual sehingga banyak sekolah yang meliburkan siswa dengan setumpuk tugas tanpa adanya penjelasan untuk masing-masing materi pelajaran. Hal tersebut membuat siswa semakin terbebani dengan banyaknya tugas dan karenanya melakukan berbagai cara agar tugas dapat selesai tanpa memikirkan pemahaman terhadap materi pelajaran. Sementara itu, kegiatan belajar di rumah juga meningkatkan penggunaan paket internet dibandingkan sebelum masa pandemi. Menurut CNN Indonesia, penggunaan paket internet mengalami peningkatan $40 \%$ sebagaimana tergambar dalam grafik penggunaan paket internet di masa pandemi Covid-19 berikut: 


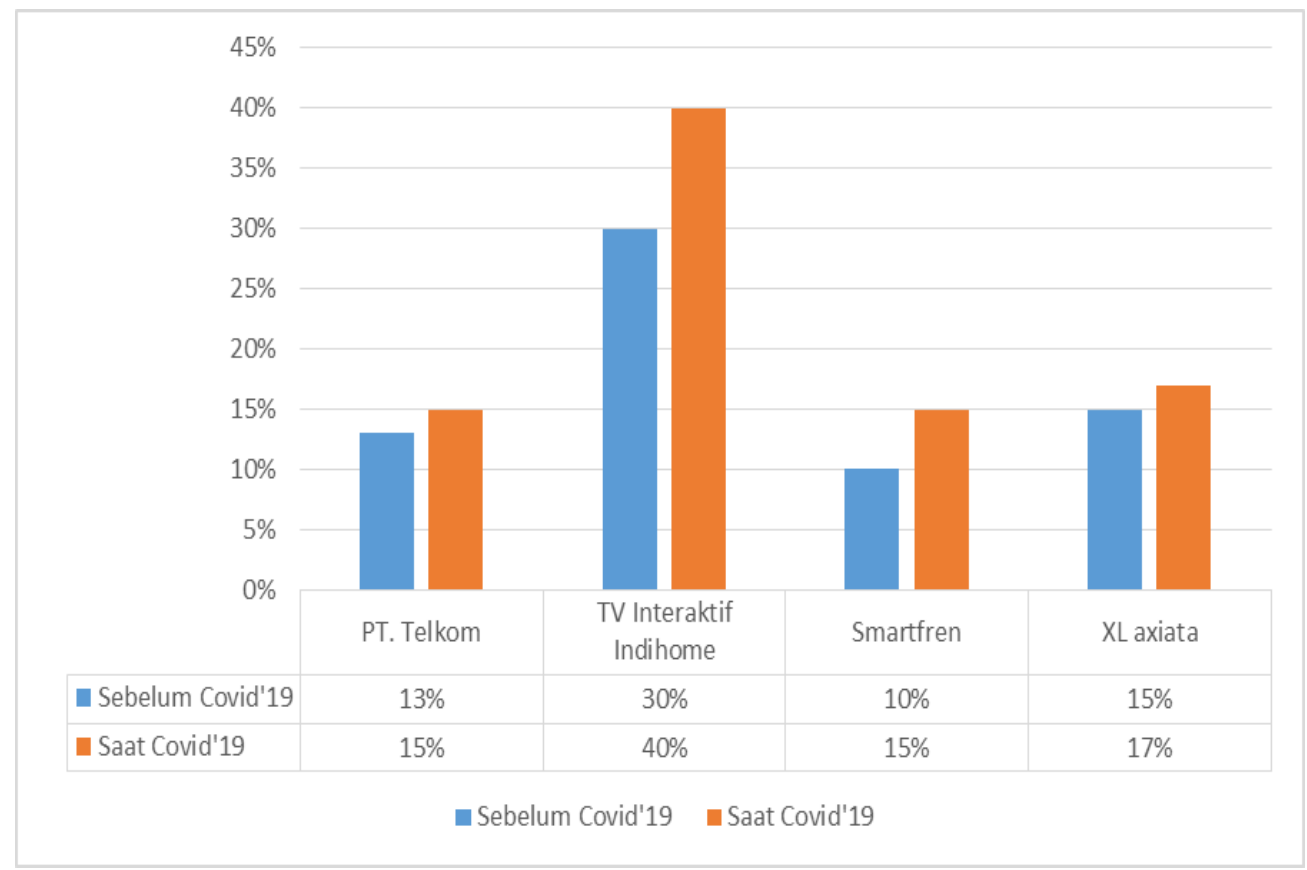

\section{Grafik 1.1}

Penggunaan Paket Internet

Data diolah dari https://www.cnnindonesia.com, 2020.

Berdasarkan grafik penggunaan data internet yang dirilis oleh CNN Indonesia di atas, tampak peningkatan penggunaan data internet. PT.Telkom dan XL Axiata menunjukkan kenaikan $2 \%$, Indihome $10 \%$ dan Smartfren 5\%. Data tersebut membuktikan bahwa belajar di rumah mengakibatkan meningkatnya penggunaan konsumsi data internet.

Kegiatan belajar di rumah dengan sistem virtual utamanya membebani orang tua siswa karena mereka harus membeli paket internet yang berarti menambah pengeluaran anggaran rumah tangga. Sebagaimana dikabarkan Media Indonesia, para orang tua siswa mengeluh akibat sekolah diliburkan sementara tugas sekolah menumpuk dan kebanyakan guru tidak memahami pembelajaran virtual. Sementara itu, Wasekjen Federasi Serikat Guru Indonesia menyatakan bahwa seharusnya tugas yang diberikan tidak membebani siswa sebab idealnya, siswa dan guru berinteraksi melalui media virtual dalam membahas materi pelajaran.(Oebadillah, 2020) Oleh sebab itu, dibutuhkan cara belajar mandiri siswa dengan pendampingan orang dewasa dalam menumbuhkan semangat belajar di rumah. Berdasarkan survei yang dilakukan oleh Kemendikbud, tingkat keberhasilan belajar di rumah adalah sebagai berikut; 


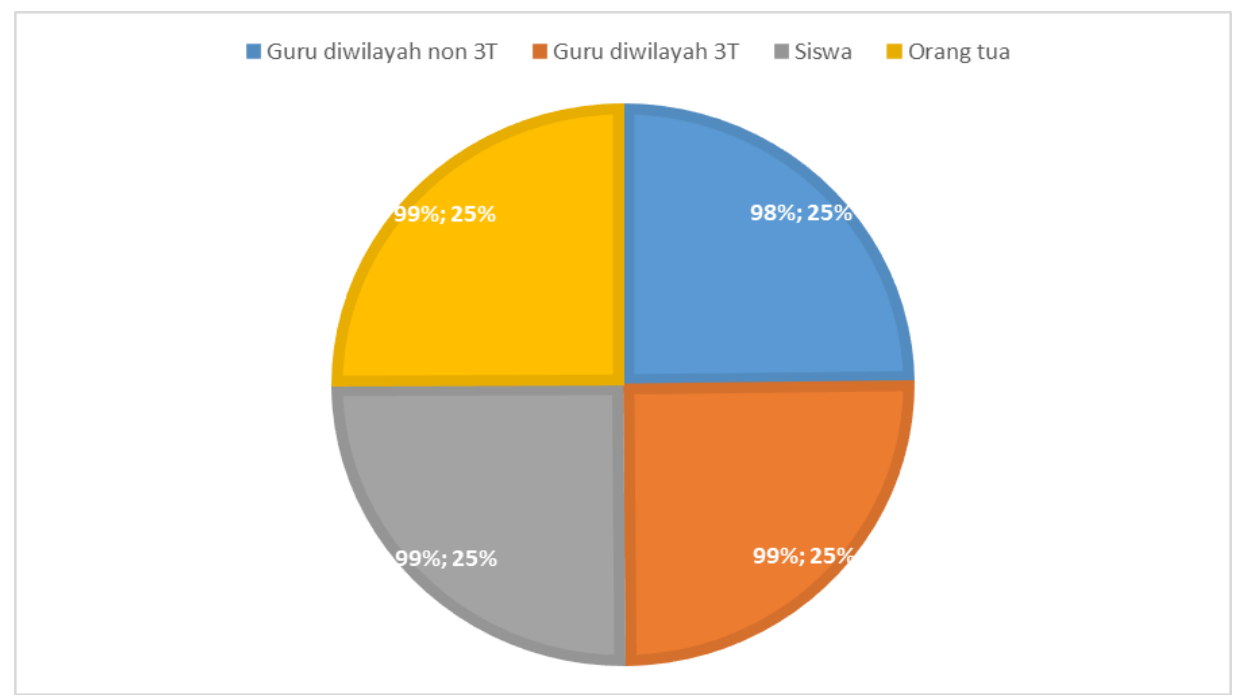

Gambar 1.2

Survei Evaluasi Belajar di Rumah

Data diolah dari https://www.kemdikbud.go.id, 2020.

Grafik di atas menunjukkan bahwa 99\% guru yang masuk dalam wilyah 3T (Terdepan, Terluar dan Tertinggal) menguasai teknik belajar di rumah secara virtual. Artinya, mereka mampu mengajari para siswa secara virtual. Sementara itu, $98 \%$ guru di wilayah non-3T juga demikian dan $99 \%$ siswa maupun orang tua juga memahami dan bisa menjalankan program belajar di rumah yang dianjurkan pemerintah. Orang tua dianggap telah mampu melakukan perannya dengan memberi pendampingan kepada siswa yang belajar di rumah, misalnya, melalui program pemerintah yang disiarkan langsung diTVRI ("Kemendikbud Rilis Hasil Survei Evaluasi Belajar dani Rumah," 2020).

Ironisnya, berdasarkan observasi di lapangan, kegiatan belajar mandiri di rumah ternyata masih kurang maksimal. Ini misalnya terjadi di Desa Taro'an Kecamatan Tlanakan, Kabupaten Pamekasan. Siswa diberi banyak tugas oleh guru guna belajar di rumah selama masa pandemi Covid-19. Ini mau tak mau sangat membebani siswa sebab banyaknya tugas tersebut tidak disertai dengan penjelasan materi sehingga siswa cenderung bosan dan lebih memilih bermain dibandingkan belajar. Kegiatan belajar di rumah inipun menjadi kurang efektif karena anjuran pemerintah yang seharusnya diterapkan dengan baik menjadi terganggu. Penyebabnyapun beragam, mulai dari media komunikasi antara guru dan siswa yang tidak dapat dimaksimalkan, faktor terbatasnya pengetahuan teknologi hingga persoalan finansial. Karena itu, perlu ditemukan solusi agar semangat belajar di rumah tetap terjaga tampa terlalu membebani siswa.

Melihat fenomena di atas, dibutuhkan gagasan baru dalam menangani tugas siswa yang menumpuk agar materi pelajaran tetap dapat dipahami tanpa tatap muka langsung. Penulis memberikan sebuah gagasan teknik 
belajar tanpa menggunakan media virtual yang menyulitkan siswa, orang tua dan guru akibat kendala yang dirasakan masing-masing. Gagasan tersebut berupa teknik visual ke dalam gambar atau lebih dikenal mind mapping. Ini dirasa penting mengingat siswa atau anak-anak menyukai gambar dan warna sehingga diharapkan penggunaan teknik ini dapat memudahkan siswa memahami materi pelajaran dengan mind mapping yang dibuat oleh pendamping belajar, baik itu guru maupun orang tua.

Teknik belajar menggunakan mind mapping ini didukung oleh beberapa penelitian. Pertama adalah karya Izkandar Zulkarnail dan Noor Amelia Sari yang berjudul "Model Penemuan Terbimbing dengan Teknik Mind Mapping untuk Meningkatkan Kemampuan Pemahaman Konsep Matematis Siswa SMP." Keduanya menunjukkan bahwa pemahaman konsep materi dengan teknik mind mapping lebih tinggi dibandingkan dengan teknik tradisional (Zulkarnain \& Sari, 2014: 240). Hal ini membuktikan bahwa belajar dengan teknik mind mapping mampu meningkatkan pemahaman belajar siswa sehinga cocok diterapkan dalam meningkatkan semangat belajar siswa di rumah.

Selain itu, kegiatan belajar dengan teknik mind mapping dikatakan mampu meningkatkan hasil belajar siswa karena merupakan cara yang paling mudah untuk memasukan informasi ke dalam otak sekaligus kembali mengambil informasi tersebut melalui proses berfikir. Penggunaan teknik gambar pada saat membuat mind mapping berasal dari pikiran manusia yang bermanfaat untuk menyediakan kunci-kunci umum sehingga membuka potensi otak dalam meningkatkan hasil belajar. Pernyataan ini didukung oleh hasil penelitian I Wayan Sarya yang berjudul "Penerapan Teknik Mind Mapping untuk Meningkatkan Hasil Belajar IPA" yang menunjukkan bahwa belajar menggunakan teknik mind mapping mampu meningkatkan hasil belajar siswa dengan cukup signifikan. Hasil belajar IPA dengan teknik mind mapping meningkat menjadi $71,90 \%$ dari sebelumnya $57,93 \%$.

Lebih jauh, teknik ini merupakan pengembangan dari kegiatan Kuliah Pengabdian Masyarakat (KPM) dalam menggalakkan gerakan literasi siswa melalui pembelajaran dengan teknik mind mapping di Desa Taro'an, Kecamatan Tlanakan, Kabupaten Pamekasan. Penerapan belajar di rumah dengan teknik mind mapping dilakukan dengan pendampingan peserta KPM dengan metode ABCD (Asset Based Community Develpoment). Meteode pendampingan ini dianggap efektif karena bisa memanfaatkan potensi yang dimiliki obyek.(Mahmudah \& Supiah, 2018) Pendampingan metode ABCD diharapkan mampu memberikan semangat belajar di rumah dengan teknik visual mind mapping untuk mengembangkan cara berpikir siswa dalam memahami sebuah materi. Teknik ini diterapkan dalam kegiatan KPM bukan tanpa alasan, karena fakta di lapangan membuktikan bahwa di masa pandemi Covid-19, kegiatan belajar di sekolah dialihkan menjadi belajar di rumah tanpa penjelasan dari seorang guru dan ini cukup memberatkan siswa maupun para orang tua.

Kegiatan belajar, lebih jauh, menjadi kurang efektif terlebih bagi siswa yang masih duduk di kelas $1 \mathrm{SD}$. Selain harus belajar mendiri di rumah 
tanpa penjelasan guru, mereka juga dibebani tugas sekolah yang demikian banyak. Oleh sebab itu, melalui kegiatan KPM, diterapkanlah sistem belajar di rumah dengan teknik mind mapping yang oleh I Wayan Sarya dianggap dapat meningkatkan hasil belajar yang lebih tinggi (Sarya, 2015). Selain itu, dengan mind mapping, orang tua dapat dengan mudah mendampingi anakanaknya belajar di rumah karena gambar cenderung disukai oleh anakanak. Mereka juga tidak perlu mengkhawatirkan kegiatan belajar di rumah yang kurang efektif karena melalui mind mapping, siswa dilatih memahami materi sesuai kemampuan motoriknya masing-masing yang dituangkan dalam sebuah gambar.

Kegiatan belajar yang dilakukan siswa di rumah, di sisi lain, dapat memotivasi orang tua untuk menjalin kedekatan dengan anak sekaligus merangsang mereka untuk mengingat materi pelajaran mereka di masa lampau. Penguatan-penguatan belajar yang demikian dapat memberi dampak yang baik, apalagi jika ditambah penggunaan teknik mind mapping secara kontinyu. Ini utamanya disebabkan karena penguatan belajar semacam itu dapat memberi ruang tersendiri bagi siswa dan orang tua dalam menjalin kedekatan sehingga belajar di rumah menjadi efektif dan efisien. Dalam konteks yang lebih khusus, kegiatan belajar di rumah dengan teknik mind mapping yang diterapkan pada siswa SD kelas 1 di Desa Taro'an Kecamatan Tlanakan Kabupaten Pamekasan dapat tetap eksis berjalan sampai pandemi Covid-19 berakhir (Ali, Atiqullah, \& Mubah, 2019).

Belajar dengan teknik visual mind mapping dilakukan dengan cara meringkas materi ke dalam bentuk virtual gambar dengan kolaborasi animasi untuk memudahkan siswa mengingat materi yang. Namun demikian, tetap diperlukan penguatan pembelajaran melalui pendampingan dalam membuat mind mapping sebelum siswa dilepaskan belajar sendiri. Harapannya, teknik ini dapat terus dikembangkan dan dilaksanakan sampai pandemi Covid-19 berakhir sebagai ganti belajar secara virtual yang sulit dilaksanakan di daerah pedesaan karena berbagai faktor. Ini juga bukan tanpa alasan, sebab teknik mind mapping juga melatih kreatifitas siswa yang sedang belajar, orang tua yang mendampingi dan guru yang mengajar.

Berdasarkan latar belakang di atas, maka dapat ditentukan rumusan penulisan sebagai berikut: 1) Bagaimanakah meningkatkan semangat belajar siswa di rumah pada masa pandemi Covid-19 dengan menggunakan mind mapping? 2) Bagaimanakah meningkatkan kemampuan siswa dalam mengaplikasikan materi pelajaran dengan teknik mind mapping? 3) Bagaimanakah meningkatkan hasil belajar siswa di rumah pada masa pandemi Covid-19 menggunakan media mind mapping?.

Tujuan penulisan secara umum adalah meningkatkan semangat belajar siswa di rumah serta mengatasi kejenuhan siswa dalam mengerjakan tugas sekolah yang menumpuk akibat Covid-19 sementara mereka tidak memahami materi pelajaran dengan baik. Adapun tujuan secara khusus adalah sebagai berikut: 1) Untuk meningkatakan semangat belajar siswa di rumah pada masa pandemi Covid-19 dengan menggunakan mind mapping; 2) Untuk meningkatkan kemampuan siswa dalam mengaplikasikan materi 
pelajaran dengan teknik mind mapping; 3) Untuk meningkatkan hasil belajar siswa di rumah ada masa pandemi Covid-19 menggunakan teknik mind mapping.

Kegiatan Pengabdian Kepada Masyarakat dengan judul "Meningkatkan Semangat Belajar di Rumah dengan Teknik Mind Mapping pada Siswa Kelas 1 SD" memiliki manfaat kepada berbagai pihak seperti berikut ini; 1) Bagi pemerintah, ini bisa menjadi solusi dalam mengatasi kegiatan belajar di rumah yang tidak dapat dilakukan secara maksimal; 2) Bagi orang tua siswa, teknik ini bisa menjadi wahana mengembangkan kemampuan peserta didik dalam menangkap informasi baru melalui teknik visual serta wujud nyata bagi siswa dalam memahami materi; 3) Bagi LP2M, penelitian ini merupakan produk publikasi karya tulis mahasiswa yang telah dieksperimentasi pada saat Kuliah Pengabdian Masyarakat (KPM). 4) Bagi siswa, hasil-hasil penelitian ini dapat menjadi bahan dalam mengembangkan kreatifitas diri.

\section{Metode Pelaksanaan}

Sasaran kegiatan pengabdian masyarakat ini adalah siswa kelas 1 SD yang tinggal di Dusun Rokoro, Desa Taro'an, Kecamatan Tlanakan, Kabupeten Pamekasan dan sedang menjalankan kegiatan belajar di rumah sebagai imbas dari pandemi Covid-19. Berdasarkan data, ada 19 siswa yang pada tahun ajaran 2019-2020 sedang menempuh pendidikan di kelas 1 SDN setempat. Rinciannya adalah 9 siswa laki-laki dan 10 siswa perempuan. Namun demikian, sampel dalam sasaran pelaksanaan belajar di rumah dengan teknik mind mapping ini terbatas pada 6 siswa karena keterbatasan ruang lingkup pelaksanaan.

Pelaksanaan kegiatan dilakukan setiap hari selama kurang lebih 3 jam dalam sekali pertemuan. Adapun tahapan pelaksanaan kegiatan meliputi: Pertama, melakukan sosialisasi pada siswa-siswa tentang manfaat dan cara membuat mind mapping sebagai solusi dalam memahami materi pelajaran. Selain itu, sosialisasi juga dilakukan pada orang tua siswa guna memberikan pengetahuan dalam mendampingi siswa belajar dirumah dengan teknik visual gambar yakni mind mapping.

Kedua, mengajarkan siswa dalam pembuatan mind mapping. Ini dimulai dari menentukan model visual sampai kata kunci yang akan dijadikan dasar mind mapping. Setelah itu, siswa diarahkan untuk memahami materi agar materi dapat direkam otak kemudian diaplikasikan dalam model visual. Upaya memahami ini bisa dilakukan dengan membaca materi pelajaran yang akan dijadikan mind mapping.

Ketiga adalah menentukan gagasan pokok dari materi yang menjadi obyek mind mapping. Gagasan pokok yang dimaksud merupakan kata kunci yang mudah diingat untuk menampung informasi di otak guna mempermudah daya ingat siswa terhadap materi.

Keempat adalah membuat model mind mapping sesuai dengan kreatifitas masing-masing siswa. Tujuannya adalah melatih siswa berkreasi dalam memahami materi pelajaran. Selain itu, ini juga dapat memberikan mereka 
kebebasan dalam menentukan model mind mapping yang diinginkan di mana hal demikian akan memberi pengaruh psikologis dalam memahami sebuah materi. Ini menjadi penting sebab psikologi begitu berperan dalam pendidikan sebagaimana ilmu pengetahuan yang berupaya memahami perbedaan keadaan peserta didik satu sama lain (Sakarebau, 2015: 97).

Kelima adalah memberi pengarahan dalam mengerjakan dan menyelesaikan tugas sekolah dengan teknik mind mapping. Hal ini bertujuan memastikan pemahaman siswa atas mind mapping yang diaplikasikan pada tugas sekolah. Tujuan lainnya adalah mengetahui sejauhmana keberhasilan mind mapping dalam mengatasi tugas sekolah siswa. Teknik mind mapping berguna sebagai pengganti belajar secara virtual yang terkendala jaringan dan finansial sehingga menyulitkan siswa dalam memahami materi.

Keenam, tahap terakhir, adalah menentukan keberhasilan mind mapping dalam meningkatkan semangat belajar siswa. Pada tahap ini, siswa dilatih secara mandiri dalam membuat mind mapping. Mind maping adalah cara mengembangkan kegiatan berpikir ke segala arah dan menangkap berbagai pikiran dalam berbagai sudut. Mind maping mengembangkan cara berpikir divergen dan berpikir kreatif. la didasarkan pada cara kerja otak yang menyimpan informasi di mana otak manusia tidak menyimpan informasi dalam kotak-kotak sel saraf yang terjejer rapi, melainkan dikumpulkan pada sel-sel saraf yang bercabang-cabang (Sholel \& Afriani, 2016: 30).

Teknik belajar dengan mind mapping dirasa sangat cocok dalam meningkatkan semangat belajar siswa karena siswa diajarkan bagaimana memahami materi secara visual. Belajar dengan teknik mind mapping sangat efektif diterapkan pada siswa kelas 1 SD sebagai pengganti belajar virtual, karena di daerah pedesaan, model virtual begitu menyulitkan siswa terutama dalam hal jaringan dan harga paket internet. Sementara itu, pemaahaman akan materi juga tidak bisa dipastikan. Untuk itu, mind mapping hadir dalam mengatasi masalah tersebt dengan mengajari siswa memahami materi sesuai dengan kreatifitasnya masing-masing.

Lebih jauh, teknik mind mapping akan berdampak secara langsung pada proses pembelajaran berikutnya. Pelatihan yang dilakukan oleh peserta Pengabdian kepada Masyarakat pada siswa SD dalam meningkatkan semangat belajar di masa pandemi Covid-19 melalui teknik ini dapat tetap berguna dalam jangka waktu panjang sehingga peserta didik akan merasa senang dalam proses pembelajaran.

\section{Hasil dan Pembahasan}

\section{a. Hasil Pelaksanaan Kegiatan}

Pelaksanaan Kegiatan Pengabdian Masyarakat yang bertema "Meningkatkan Semangat Belajar di Rumah dengan Teknik mind mapping pada Siswa kelas 1 SD di Dusun Rokoro Desa Taro'an, Kecamatan Tlanakan, Kabupaten Pamekasan" dilaksanakan sesuai jadwal yang direncanakan, yakni setiap Senin sampai Sabtu. Kegiatan dilaksanakan di Desa Taro'an, Kecamatan Tlanakan, Kabupaten Pamekasan, sejak Selasa, 
02 Juni 2020 hingga Sabtu, 27 Juni 2020. Secara sistematis, jadwal Kegiatan Pengabdian Masyarakat dengan menerapkan belajar di rumah menggunakan teknik mind mapping adalah sebagai berikut:

Tabel 1. Jadwal Kegiatan Meningkatkan Semangat Belajar di Rumah dengan Teknik Mind Mapping pada Siswa Kelas 1 SD di Dusun Rokoro, Desa Taro'an, Kecamatan Tlanakan, Kabupaten Pamekasan

\begin{tabular}{|c|c|}
\hline Waktu & Kegiatan \\
\hline 02 Juni 2020 & Persiapan \\
\hline 03-04 Juni 2020 & Sosialisasi \\
\hline 05-06 Juni 2020 & Mengajarkan pembuatan Mind Mapping \\
\hline 07 Juni 2020 & Libur \\
\hline 08-10 Juni 2020 & $\begin{array}{l}\text { Mengajarkan pencarian gagasan pokok dalam } \\
\text { suatu kalimat yang mudah diingat }\end{array}$ \\
\hline 11-13 Juni 2020 & Mengajarkan teknik membaca Mind Mapping \\
\hline 14 Juni 2020 & Libur \\
\hline 15-17 Juni 2020 & $\begin{array}{l}\text { Mengajarkan penyelesaian tugas sekolah melalui } \\
\text { teknik mind mapping }\end{array}$ \\
\hline 18-20 Juni 2020 & $\begin{array}{l}\text { Praktik mandiri membuat Mind Mapping sesuai } \\
\text { materi pelajaran }\end{array}$ \\
\hline 21 Juni 2020 & Libur \\
\hline 22-24 Juni 2020 & $\begin{array}{l}\text { Praktik mengajarkan penyelesaian tugas sekolah } \\
\text { melalui teknik mind mapping }\end{array}$ \\
\hline 25-26 Juni 2020 & Evaluasi kegiatan \\
\hline 27 Juni 2020 & Penutupan \\
\hline
\end{tabular}

Kegiatan Pengabdian Masyarakat dilaksanakan setiap hari selama 22 (dua puluh dua) kali pertemuan tatap muka dengan para siswa. Agenda pertama adalah persiapan materi sebagai bahan sosialisasi pada siswa dan orang tua siswa. Ini kemudian dilanjutkan dengan pertemuan kedua dan ketiga yakni pelaksanaan sosialisasi mengenai belajar dengan teknik mind mapping kepada orang tua dan siswa. Hal ini dilakukan sebagai pengenalan terhadap teknik belajar dengan media visual kepada orang tua selaku pendamping dan siswa sebagai obyek pelaksanaan teknik mind mapping. Sosialisasi meliputi paparan perihal cara penerapan hingga manfaat teknik ini. Pertemuan keempat dan kelima, selanjutnya, adalah praktik mengajarkan pembuatan Mind Mapping. Pada pertemuan ini, penulis selaku peserta Kuliah Pengabdian Masyarakat melaksanakan kegiatan mengajar dan mendampingi siswa kelas $1 \mathrm{SD}$ yang ada di Dusun Rokoro dalam melaksanakan kegiatan belajar di rumah dengan teknik mind mapping.

Pertemuan keenam, ketujuh dan kedelapan beragendakan pengajaran bagaimana mencari gagasan pokok dalam suatu kalimat yang mudah diingat. Pada tiga pertemuan ini, siswa diajari mencari ide pokok atau kata 
kunci yang bisa dijadikan poin dalam mind mapping dengan membaca materi yang memuat kata kunci mind mapping dan kata yang mudah diingat dan direkam otak para siswa. Setelah itu, pada tiga pertemuan selanjutnya, yakni pertemuan kesembilan, kesepuluh dan kesebelas berisi pengajaran teknik membaca Mind Mapping. Setelah tahap memahami kata kunci dari materi, siswa selanjutnya diarahkan melakukan pembacaan melalui media visual mind mapping.

Ini kemudian dilanjutkan dengan pertemuan kedua belas, ketiga belas dan keempat belas yang berisi pengajaran bagaimana siswa menyelesaikan tugas sekolah melalui teknik mind mapping. Di masa pandemi Covid-19 ketika belajar 'dipindahkan' ke rumah, siswa diberikan cukup banyak tugas sehingga mind mapping menjadi penting diterapkan guna memahamkan materi yang tidak dijelaskan guru dan memastikan pemahaman siswa. Tak hanya memahami materi, ini juga akan memudahkan siswa menjawab atau menyelesaikan tugas yang diberikan guru.

Setelah memastikan pemahaman siswa, proses kemudian dilanjutkan dengan pertemuan kelima belas, keenam belas dan ketujuh belas yang berisi praktik mandiri membuat Mind Mapping sesuai materi pelajaran. Pada pertemuan ini, siswa diarahkan untuk membuat mind mapping secara mandiri sesuai dengan tugas mandiri dari guru masing-masing. Mereka diberi kebebasan membuat mind mapping sesuai kemauan namun harus menyesuaikan dengan materi pelajaran.

Sementara itu pertemuan kedelapan belas, kesembilan belas dan kedua puluh berisi praktik mengajarkan siswa dalam menyelesaikan tugas sekolah melalui teknik mind mapping. Pada peretemuan, siswa diarahkan menyelesaikan tugas sekolah masing-masing di samping memastikan pemahaman mereka atas materi yang juga difasilitias oleh teknik mind mapping. Dua pertemuan terakhir, yakni kedua puluh satu dan kedua puluh dua berisi evaluasi dari penerapan belajar di rumah dengan menggunakan mind mapping. Evaluasi menunjukkan bahwa hasil belajar menggunakan media visual mampu membuat siswa bersemangat dalam belajar karena kebanyakan mereka menyukai aktivitas menggambar dan mencari kanta kunci yang bisa dijakan poin inti dalam mind mapping.

\section{b. Pembahasan}

Kegiatan Kuliah Pengabdian masyarakat yang berjudul "Meningkatkan Semangat Belajar di Rumah dengan Teknik Mind Mapping Pada Siswa Kelas 1 SD di Dusun Rokoro, Desa Taro'an, Kecamatan Tlanakan, Kabupaten Pamekasan," telah dilaksanakan selama 22 kali pertemuan. Pertemuan pertama yang beragendakan persiapan materi bahan pembelajaran dengan teknik mind mapping dilaksanakan pada Selasa, 02 Juni 2020. Peneliti mendatangi obyek yang akan menjalani eksperimentasi penerapan teknik mind mapping dalam memahami materi pelajaran sekolah. Selanjutnya, pertemuan kedua dan ketiga berisi kegiatan sosialisasi belajar dengan teknik visual. 
Pada pertemuan keempat dan kelima (05-06 Juni 2020), siswa diajarkan membuat Mind Mapping. Agenda ini dilaksanakan di sekitar kediaman siswa. Selanjutnya pada pertemuan keenam, ketujuh dan kedelapan, siswa diajarkan mencari gagasan pokok dalam suatu kalimat yang mudah diingat dan akan menjadi poin dalam mind mapping. Dalam proses ini, penulis mengamati siswa secara langsung guna memastikan sejauh mana mereka memahami materi pelajaran. Selanjutnya pada pertemuan kesembilan, kesepuluh dan kesebelas, siswa diajarkan bagaimana membaca dan mencerna apa yang tertulis dalam mind mapping.

Pertemuan kedua belas, ketiga belas dan keempat belas, sementara itu, mengajarkan siswa bagaimana menyelesaikan tugas sekolah melalui teknik mind mapping. Adapun pertemuan kelima belas, keenam belas dan ketujuh belas adalah praktik mandiri membuat Mind Mapping sesuai materi pelajaran. Pada pertemuan ini, siswa diarahkan untuk membuat mind mapping secara mandiri sesuai dengan tugas mandiri dari guru masingmasing dengan. Mereka diberi kebebasan membuat mind mapping sesuai kemauan namun harus sesuai dengan materi pelajaran.

Tiga pertemuan selanjutnya (18, 19 dan 20) dilanjutkan dengan praktik menyelesaikan tugas sekolah melalui teknik mind mapping. Sementara itu, dua pertemuan selanjutnya yakni kedua puluh satu dan kedua puluh dua, berisi evaluasi dari penerapan mind mapping selama proses pembelajaran di rumah. Berdasarkan evaluasi tersebut, diketahui bahwa teknik ini mampu menarik minat siswa dalam belajar sebab anak-anak umumnya menyukai gambar. Dari sini, diketahui bahwa penelitian ini sejalan dengan penelitian yang dilakukan oleh Iskandar Zulkarnain dan Noor Amalia Sari yang berjudul "Model Penemuan Terbimbing dengan Teknik Mind Mapping untuk Meningkatkan Kemampuan Pemahaman Konsep Matematis Siswa SMP." Penelitian tersebut menunjukkan bahwa pembelajaran matematika dengan teknik mind mapping memberi dampak positif berupa kemampuan siswa memahami konsep matematis hingga respon yang mereka tunjukkan.(Zulkarnain \& Sari, 2014) Ini, dengan demikian, cukup membuktikan bahwa mind mapping mampu meningkatkan semangat belajar di rumah bagi para siswa kelas 1 SD yang terlibat dalam penelitian ini.

\section{Kesimpulan}

Pelaksanakan Kuliah Pengabdian Masyarakat (KPM) dengan tema "Meningkatkan Semangat Belajar di Rumah dengan Teknik Mind Mapping pada Siswa Kelas 1 SD di Dusun Rokoro Desa Taro'an, Kecamatan Tlanakan, Kabupaten Pamekasan" dapat berjalan dengan baik sesuai prosedur karena dukungan dan partisipasi para siswa dan orang tua.

Temuan dari Kuliah Pengabdian Masyarakat (KPM) ini menunjukkan bahwa model belajar dengan teknik mind mapping dapat memberi semangat belajar di rumah bagi siswa kelas 1 SD di Dusun Rokoro, Desa Taro'an, Kecamatan Tlanakan, Kabupaten Pamekasan. Hal ini dapat dilihat dari pemahaman siswa yang baik dan benar terhadap materi pelajaran serta kemampuan mereka menyelesaikan tugas sekolah dengan baik berbekal 
teknik visual mind mapping. Lebih jauh, siswa terlatih secara mandiri dalam memahami materi tanpa harus mengikuti pembelajaran virtual di masa pandemi Covid-19 ini.

\section{Rekomendasi}

Berdasarkan temuan hasil Kuliah Pengabdian Masyarakat (KPM) yang berjudul "Meningkatkan Semangat Belajar di Rumah dengan Teknik Mind Mapping pada Siswa Kelas 1 SD di Dusun Rokoro Desa Taro'an Kecamatan Tlanakan Kabupaten Pamekasan, direkomendasikan beberapa hal berikut: 1) Pentingnya melakukan pengabdian masyarakat guna membatu mengatasi masalah yang ada di masyarakat. 2) Pentingnya memberikan solusi bagi siswa yang kesulitan memahami materi pelajaran di sekolah. 3) Perlunya kerja sama dengan orang tua selaku wali murid. 4) Perlunya melanjutkan pembelajaran dengan teknik visual mind mapping setelah pandemi berakhir dan pembelajaran di sekolah kembali normal guna melatih kreatifitas siswa dan mengembangkan pemahaman materi di bawah pengarahan guru.

\section{Daftar Pustaka}

Ali, N., Atiqullah, \& Mubah, H. Q. (2019). Penguatan Pembelajaran PKBM Putro Wali dengan Model Lesson Study di Ponpes Nurul Ulum Tagrineh Manoan Kecamatan Kokop Kabupaten Bangkalan. Pêrdikan: Journal of Community Engagement, 1(2), 61-68.

Fauziah, A., Rosnaningsih, A., \& Azhar, S. (2017). Hubungan antara Motivasi Belajar dengan Minat Belajar Siswa Kelas IV SDN Pores Gaga 05 Kota Tangerang. Jurnal JPSD, 4(1), 47-53.

Indonesia, C. N. N. (2020, September 6). Pengguna Internet Kala WFH Corona Meningkat 40 Persen di RI. Diambil 6 September 2020, dari Teknologi website: https://www.cnnindonesia.com/teknologi/20200408124947-213491594/pengguna-internet-kala-wfh-corona-meningkat-40-persen-di-ri.

Kemendikbud Rilis Hasil Survei Evaluasi Belajar dari Rumah. (2020, Mei 5). Diambil 9 Juni 2020, dari Kementerian Pendidikan dan Kebudayaan website:

https://www.kemdikbud.go.id/main/blog/2020/05/kemendikbud-rilis-

hasil-survei-evaluasi-belajar-dari-rumah

Mahmudah, N., \& Supiah. (2018). Pemberdayaan Pada Anak-anak Dolly di SMA Antartika Surabaya dengan Metode Asset Based Community Development. Madani, 1(1), 17-29.

Oebadillah, S. (2020, Maret 18). Belajar di Rumah Bukan Bebani Siswa Dengan Tugas [Humaniora].

Sakarebau, J. (2015). Memahami Peran Psikologi Pendidikan Bagi Pembelajaran. Jurnal Teknologi dan Pendidikan Kristen Kontekstual, 1(1), 96-111. 
Sarya, I. W. (2015). Penerapan Teknik Mind Mapping untuk Meningkatkan Hasil Belajar IPA. Proceedings Seminar Nasional FMIPA UNDIKSHA $V$, 96-99.

Sholel, K., \& Afriani, S. (2016). Teknik Mind Mapping sebagai Upaya untuk Meningkatkan Keterampilan Menulis Cerpen Pada Siswa SMA. JPSE, 26-45.

Susanto, A. (2013). Teori Belajar dan Pembelajaran di Sekolah Dasar. Jakarta: Pernada Media Group.

Zulkarnain, I., \& Sari, N. A. (2014). Model Penemuan Terbimbing dengan Teknik Mind Mapping untuk Meningkatkan Kemampuan Pemahaman Konsep Matematis Siswa SMP. EDU-MAT Jurnal Pendidikan Matematika, 2(3), 240-249. 